\title{
EFFECTS OF HEAVY METAL PB AND CD STRESS ON PHYSIOLOGICAL CHARACTERISTICS OF JAPANESE HONEYSUCKLE
}

\author{
MAO, X. F. - XU, X. B. - CHEN, L. L.* \\ School of Life Science and Technology, Xinxiang University, Xinxiang 453000, China \\ *Corresponding author \\ e-mail: 3193175505@qq.com
}

(Received 29 $9^{\text {th }}$ Dec 2018 ; accepted $8^{\text {th }}$ Mar 2019)

\begin{abstract}
To evaluate physiological changes of Japanese honeysuckle under lead and cadmium stress, pot-plant experiment was adopted to discover heavy metal $\mathrm{Pb}$ or $\mathrm{Cd}$ single stress and $\mathrm{Pb}+\mathrm{Cd}$ combined stress on part of physiological parameters of. Japanese honeysuckle. The results showed that under the same treatment, as time prolonged, the content of soluble sugar and soluble protein was decreased, the activity of SOD declined, the amount of free proline and MDA increased and the activity of CAT elevated. Under $\mathrm{Pb}$ stress only, total Chlorophyll content rose first and dropped afterwards and POD activity increased, however, under $\mathrm{Cd}$ stress only and $\mathrm{Pb}+\mathrm{Cd}$ stress, both THCL content and POD activity first rose and then declined. In addition, under $\mathrm{Pb}$ or $\mathrm{Cd}$ single stress and combined stress, as treatment concentration increased, the contents of soluble sugar, soluble protein, free proline and MDA increased accompanied by POD, CAT and SOD activity increased while TCHL content decreased. All these indicate that under certain range of heavy metal stress, Japanese honeysuckle can reduce metabolic disorder plant damage caused by heavy metal stress through increasing osmotic regulating substances of leaves and inducing scavenging system of active oxygen.
\end{abstract}

Keywords: Japanese honeysuckle, heavy metal stress, antioxidative enzyme, chlorophyll, osmosis substances

Abbreviations: SOD: superoxide dismutase, MDA: malondialdehyde, CAT: catalase, POD: peroxidase, CHL a: chlorophyll a, CHL b: chlorophyll b, TCHL: total chlorophyll, Pb: lead, Cd: cadmium

\section{Introduction}

With the acceleration of industrialization and urbanization in China, the issue of environmental pollution has become increasingly prominent, especially air, soil and water pollution caused by man-made factors, which have not only influenced urban ecosystem, but also greatly changed the quality of farmland. Among all the factors, heavy metals in the soil are main sources of pollution and the situation is getting worse (Liu et al., 2016).

$\mathrm{Pb}$ and $\mathrm{Cd}$ are two main heavy metal pollutants in soil from industrial and agricultural activities such as mining and smelting of metalliferous ores, wastewater irrigation and abuse of chemical fertilizers and pesticides (Wang et al., 2015; AbadValle et al., 2016). Both of them, which can stay in the soil for a long time, are easy to accumulate and be absorbed by plants. In plants, they accumulate a lot in various organs not only to cause changes in morphology, physiology and biochemistry, structure, but also to endanger human health through the food chain (Khan et al., 2018). In soil, Cd is easily absorbed by plant roots and transported to other parts of plants, which is harmful to organisms even at very low concentration (Hu et al., 2014; Ran et al., 2016). In many cases, photosynthetic organs are damaged, inducing net photosynthesis rate decreased and leaf senescence accelerated, thus plant growth is inhibited, causing decrease of 
chlorophyll content (Liu et al., 2015; Silva et al., 2017), stomatal closure and affecting water metabolism and nutrient imbalance caused (Schmidt et al., 2015; Anjum et al., 2016) by $\mathrm{Cd}$ can also change the activities of several enzymes relating to nitrogen metabolism, carbohydrate metabolism and sulfur metabolism (Mostofa et al., 2015). Pb is another kind of common harmful heavy metal (Okpoli, 2019). Pb entering into plants can alter cell membrane osmosis and cause a certain degree of damage to sub-micro structures like chloroplast, mitochondria and nucleus (Muhammad et al., 2018). Pb can competitively replace metal elements in the active sites of some enzymes and affect the normal activities of enzymes, thereby causing a series of disorders of physiological processes such as photosynthesis, respiration, nitrogen metabolism, nucleic acid metabolism (Hossain, 2019). It indirectly affects plant growth through antagonism leading to element imbalance and nutritious stress.

Japanese honeysuckle (Lonicera japonica T.) belongs to Caprifoliaceae Lonicera. Its flower buds, which can be used as medicine with heat-clearing, detoxifying and antiinflammatory effects ( $\mathrm{Li}$ et al., 2017; Wang et al., 2017) is a famous Chinese herbal medicine and widely planted in China. Japanese honeysuckle of Fengqiu county, Henan province, which is famous for its long planting history and high quality, has become the largest planting and export base in China. Their products are exported to Japan, Singapore and southeast Asia, etc. In recent years, the phenomenon of heavy metal exceeded in Chinese herbal medicine has caused great concern. It is closely related to Chinese herbal medicine quality and safety (Chen et al., 2017). As the main origin of Japanese honeysuckle, the farmland of Fengqiu is also polluted with the acceleration of industrialization and urbanization in Henan, affecting the production and quality of Japanese honeysuckle (Sarker et al., 2019). For previous studies of Japanese honeysuckle, the focuses were mostly on the efficacy of its medicinal ingredients, extraction and processing and seldom on heavy metal's physiological influence. The purpose of our research is to probe the physiological and biochemical reactions and tolerance of Japanese honeysuckle, which may provide research basis for the further study of the accumulation characteristics of heavy metals in it and to provide evidence for its scientific planting to ensure its quality, production and clinical medication safety (Ogunkunle et al., 2019).

\section{Materials and methods}

\section{Materials}

The tested yearling seedling of tree-shaped Japanes honeysuckle was provided by the Four Seasons Honeysuckle Seedlings Company in Jia Zhuang, Fengqiu County, Henan province and the tested soil was also collected from the farmland in the Japanese honeysuckle plant base in Jia Zhuang. After naturally dried, the soil was sieved, crushed and put over $5 \mathrm{~mm}$ sieve with the physiological and chemical values and the background values of $\mathrm{Pb}, \mathrm{Cd}$ were determined (see Table 1).

Table 1. The physiological and chemical values of tested soil

\begin{tabular}{c|c|c|c|c|c|c}
\hline \multirow{2}{*}{$\mathbf{p H}$} & \multirow{2}{*}{$\begin{array}{c}\text { Organics } \\
(\mathbf{m g} / \mathbf{k g})\end{array}$} & \multicolumn{3}{|c|}{ Main nutrients (mg/kg) } & \multicolumn{2}{c}{ Heavy metals (mg/kg) } \\
\cline { 3 - 7 } & Available N & Available P & Available K & Cd & pb \\
\hline 7.8 & 11.40 & 91.40 & 20.40 & 376 & 0.035 & 92.40 \\
\hline
\end{tabular}




\section{Research design}

The experiment was conducted in Xinxiang University, Hongqi District, Xinxiang City, Henan Province, China $\left(35.26^{\circ} \mathrm{N}, 113.97^{\circ} \mathrm{E}\right)$. It is a warm temperate continental monsoon climate with an average annual temperature of $14.2{ }^{\circ} \mathrm{C}$, an average annual precipitation of $573.4 \mathrm{~mm}$, an average annual sunshine time of $2400 \mathrm{~h}$, an average annual humidity of $68.0 \%$, and a frost-free period of 220 days (Sufiyan et al., 2018).

Test soil was polluted by $\mathrm{Pb}\left(\mathrm{NO}_{3}\right)_{2}$ and $\mathrm{CdCl}_{2}$ as sources of $\mathrm{Pb}$ and $\mathrm{Cd}$. The four treatments of this research were designed according to the amount of pure heavy metals in each pot of soil, which was measured by its weight in each kilo of dry soil. Treatment one was taken as control with no $\mathrm{Pb}$ and $\mathrm{Cd}$ added (CK). Treatment two only had $\mathrm{Pb}$ stress of different concentrations: $\mathrm{L}_{1}(\mathrm{~Pb} 400 \mathrm{mg} / \mathrm{kg}), \mathrm{L}_{2}(\mathrm{~Pb} 600 \mathrm{mg} / \mathrm{kg}), \mathrm{L}_{3}(\mathrm{~Pb}$ $800 \mathrm{mg} / \mathrm{kg}), \mathrm{L}_{4}(\mathrm{~Pb} 1000 \mathrm{mg} / \mathrm{kg})$. Treatment three was under $\mathrm{Cd}$ stress of different concentrations: $\mathrm{C}_{1}(\mathrm{Cd} 0.5 \mathrm{mg} / \mathrm{kg}), \mathrm{C}_{2}(\mathrm{Cd} 1.0 \mathrm{mg} / \mathrm{kg}), \mathrm{C}_{3}(\mathrm{Cd} 5.0 \mathrm{mg} / \mathrm{kg}), \mathrm{C}_{4}(\mathrm{Cd}$ $10.0 \mathrm{mg} / \mathrm{kg}$ ). Treatment four had $\mathrm{Pb}$ and $\mathrm{Cd}$ combined stress of different concentrations: $\mathrm{L}_{1}+\mathrm{C}_{1}(400 \mathrm{mg} / \mathrm{kg} \mathrm{Pb}+0.5 \mathrm{mg} / \mathrm{kg} \mathrm{Cd}), \mathrm{L}_{2}+\mathrm{C}_{2}(600 \mathrm{mg} / \mathrm{kg} \mathrm{Pb}+1.0 \mathrm{mg} / \mathrm{kg} \mathrm{Cd}), \mathrm{L}_{3}+$ $\mathrm{C}_{3}(800 \mathrm{mg} / \mathrm{kg} \mathrm{Pb}+5.0 \mathrm{mg} / \mathrm{kg} \mathrm{Cd}), \mathrm{L}_{4}+\mathrm{C}_{4}(1000 \mathrm{mg} / \mathrm{kg} \mathrm{Pb}+10.0 \mathrm{mg} / \mathrm{kg} \mathrm{Cd})$. There were 12 treatments in total and each one repeated five times. All the reagents were added to the prepared $7 \mathrm{~kg}$ soil in pots $(25 \mathrm{~cm} \times 14 \mathrm{~cm} \times 18 \mathrm{~cm})$ according to the concentration of each treatment. In order to ensure sufficient nutrients for plant growth, $0.2 \mathrm{~g}$ of urea and $0.1 \mathrm{~g}$ of potassium dihydrogen phosphate were applied to every $\mathrm{kg}$ of soil (Samsudin et al., 2018). The soil was permitted to equilibrate for $30 \mathrm{~d}$ after lead and cadmium contamination. $30 \mathrm{~d}$ later, one healthy seedling of similar growth status was planted in each pot, which were placed in greenhouse in February, 2017 and given 300$500 \mathrm{ml}$ Deionized water each pot every day during the research. In order to simulate the natural growth conditions of Japanese honeysuckle, the greenhouse uses natural light source and keep ventilation. At the same time, the temperature is consistent with the external temperature (Monteiro Junior et al., 2019).

\section{Determining items and methods}

At 45 and 90 days after stress respectively, leaf determination was conducted for each plant. 4-5 pairs of mature leaves under the top buds of new shoots Japanese honeysuckle were quickly packed into plastic bags, sealing tightly for determination. In the whole research, 8 items were determined with different procedures, including acetone extraction method for Chlorophyll content (Arnon, 1949). anthrone method for soluble sugar content (Fairbairn, 1953). Determination of proline by Acidic Ninhydrin (Walter and John, 1955). coomassie blue staining for soluble protein content (Sedmak and Grossberg, 1977). Thiobarbituric acid method for MDA, malanodialdehyde (MDA) content was determined from the difference (A532-A600) in absorbance by using Beerand Lambert's equation and expressed in terms of umol g-1 (Jambunathan, 2010). Guaiacol colorimetric method (Bestwick et al., 1998) for POD activity with each OD value changes 0.01 per minute as a enzyme activity unit (U), NBT illumination method for SOD activity with the amount of enzymes for inhibiting 50\% of NBT illumination as an enzyme activity unit (U) (Elavarthi and Martin, 2010). Catalase activity was measured according to (Aebi, 1984) where $\mathrm{H}_{2} \mathrm{O}_{2}$ decomposition is followed spectrophotometrically at $240 \mathrm{~nm}$ (Oyedotun, 2019). One enzyme activity unit is equal to $1 \mathrm{mmol} \mathrm{H}_{2} \mathrm{O}_{2}$ decomposed per minute (Elavarthi and Martin, 2010). Each procedure 
was repeated three times to get the mean value. Data processing and analysis were conducted by Excel 2007 and SPSS 19.0.

\section{Results and analysis}

\section{Chlorophyll content}

As the pigment for photosynthesis, the content of chlorophyll is a predominant reflective parameter for photosynthetic capacity of plant leaves (Riccardi et al., 2014). See Table 2, at $45 \mathrm{~d}$ and $90 \mathrm{~d}$, under single and combined stress, Chl a appears an apparent tendency of declining. When cadmium concentration was $1.0 \mathrm{mg} / \mathrm{kg}$ and stress was 90 days, $\mathrm{Chl}$ a decreased by $59.11 \%$ compared to $\mathrm{CK}$, and $\mathrm{Chl} \mathrm{b}$ decreased by $77.89 \%$ when lead concentration was $1000 \mathrm{mg} / \mathrm{kg}$ and stress was 90 days. The content of $\mathrm{Chl} \mathrm{b}$ decreased more than $\mathrm{Chl}$ a. Therefore, $\mathrm{Chl} b$ is more sensitive than $\mathrm{Chl}$ a under heavy metal stress. Nevertheless, under the same treatment, CHLa, CHL b and TCHL showed downtrend with time increased, manifesting the inhibition effect of heavy metal stress for chlorophyll synthesis.

Table 2. Effect of $\mathrm{Pb}, \mathrm{Cd}$ stress on chlorophyll content $\mathrm{mg} / \mathrm{g}$

\begin{tabular}{c|c|c|c|c|c|c|c}
\hline \multirow{2}{*}{ Element } & \multirow{2}{*}{$\begin{array}{c}\text { Treat- } \\
\text { ment }\end{array}$} & \multicolumn{2}{|c|}{ Chl a } & \multicolumn{2}{c|}{ Chl b } & \multicolumn{2}{c}{ Total Chl } \\
\cline { 3 - 8 } & $\mathbf{4 5 d}$ & $\mathbf{9 0 d}$ & 45d & 90d & 45d & 90d \\
\hline \multirow{5}{*}{$\mathrm{Cd}$} & $\mathrm{CK}$ & $1.385 \pm 0.030 \mathrm{a}$ & $1.230 \pm 0.059 \mathrm{a}$ & $0.986 \pm 0.007 \mathrm{a}$ & $0.882 \pm 0.019 \mathrm{a}$ & $2.371 \pm 0.064 \mathrm{a}$ & $2.112 \pm 0.083 \mathrm{a}$ \\
& 1 & $1.021 \pm 0.052 \mathrm{~b}$ & $0.528 \pm 0.044 \mathrm{~b}$ & $0.793 \pm 0.060 \mathrm{a}$ & $0.323 \pm 0.005 \mathrm{~b}$ & $1.814 \pm 0.210 \mathrm{~b}$ & $0.851 \pm 0.017 \mathrm{~b}$ \\
& 2 & $0.956 \pm 0.027 \mathrm{bd}$ & $0.503 \pm 0.029 \mathrm{~b}$ & $0.710 \pm 0.045 \mathrm{a}$ & $0.308 \pm 0.004 \mathrm{c}$ & $1.666 \pm 0.085 \mathrm{bd}$ & $0.811 \pm 0.014 \mathrm{~b}$ \\
& 3 & $0.869 \pm 0.004 \mathrm{bd}$ & $0.521 \pm 0.021 \mathrm{~b}$ & $0.629 \pm 0.065 \mathrm{ac}$ & $0.266 \pm 0.010 \mathrm{~d}$ & $1.498 \pm 0.035 \mathrm{bd}$ & $0.787 \pm 0.017 \mathrm{~b}$ \\
& 4 & $0.807 \pm 0.060 \mathrm{~cd}$ & $0.549 \pm 0.013 \mathrm{~b}$ & $0.475 \pm 0.045 \mathrm{bc}$ & $0.236 \pm 0.001 \mathrm{e}$ & $1.282 \pm 0.025 \mathrm{~cd}$ & $0.785 \pm 0.014 \mathrm{~b}$ \\
\hline \multirow{5}{*}{$\mathrm{Pb}$} & $\mathrm{CK}$ & $1.385 \pm 0.030 \mathrm{a}$ & $1.230 \pm 0.059 \mathrm{a}$ & $0.986 \pm 0.007 \mathrm{a}$ & $0.882 \pm 0.019 \mathrm{a}$ & $2.371 \pm 0.064 \mathrm{a}$ & $2.112 \pm 0.083 \mathrm{a}$ \\
& 1 & $0.976 \pm 0.022 \mathrm{~b}$ & $1.023 \pm 0.019 \mathrm{~b}$ & $0.296 \pm 0.009 \mathrm{~b}$ & $0.328 \pm 0.042 \mathrm{~b}$ & $1.272 \pm 0.017 \mathrm{~b}$ & $1.351 \pm 0.114 \mathrm{~b}$ \\
& 2 & $0.833 \pm 0.025 \mathrm{c}$ & $0.794 \pm 0.004 \mathrm{c}$ & $0.275 \pm 0.005 \mathrm{bd}$ & $0.246 \pm 0.068 \mathrm{~b}$ & $1.108 \pm 0.007 \mathrm{c}$ & $1.040 \pm 0.063 \mathrm{c}$ \\
& 3 & $0.821 \pm 0.007 \mathrm{c}$ & $0.770 \pm 0.051 \mathrm{c}$ & $0.258 \pm 0.001 \mathrm{~cd}$ & $0.214 \pm 0.049 \mathrm{~b}$ & $1.079 \pm 0.022 \mathrm{c}$ & $0.984 \pm 0.060 \mathrm{c}$ \\
& 4 & $0.823 \pm 0.013 \mathrm{c}$ & $0.745 \pm 0.042 \mathrm{c}$ & $0.226 \pm 0.009 \mathrm{e}$ & $0.195 \pm 0.050 \mathrm{~b}$ & $1.049 \pm 0.010 \mathrm{c}$ & $0.94 \pm 0.038 \mathrm{c}$ \\
\hline \multirow{5}{*}{$\mathrm{Cd}+\mathrm{Pb}$} & $\mathrm{CK}$ & $1.385 \pm 0.030 \mathrm{a}$ & $1.230 \pm 0.059 \mathrm{a}$ & $0.986 \pm 0.007 \mathrm{a}$ & $0.882 \pm 0.019 \mathrm{a}$ & $2.371 \pm 0.064 \mathrm{a}$ & $2.112 \pm 0.083 \mathrm{a}$ \\
& 1 & $0.872 \pm 0.031 \mathrm{~b}$ & $0.765 \pm 0.049 \mathrm{~b}$ & $0.236 \pm 0.008 \mathrm{~b}$ & $0.274 \pm 0.036 \mathrm{~b}$ & $1.108 \pm 0.026 \mathrm{~b}$ & $1.039 \pm 0.011 \mathrm{~b}$ \\
& 2 & $0.850 \pm 0.016 \mathrm{be}$ & $0.754 \pm 0.006 \mathrm{bd}$ & $0.258 \pm 0.001 \mathrm{bd}$ & $0.230 \pm 0.033 \mathrm{~b}$ & $1.108 \pm 0.023 \mathrm{~b}$ & $0.984 \pm 0.078 \mathrm{~b}$ \\
& 3 & $1.051 \pm 0.015 \mathrm{c}$ & $0.835 \pm 0.011 \mathrm{~b}$ & $0.303 \pm 0.008 \mathrm{c}$ & $0.182 \pm 0.058 \mathrm{~b}$ & $1.354 \pm 0.012 \mathrm{c}$ & $1.017 \pm 0.033 \mathrm{~b}$ \\
& 4 & $0.791 \pm 0.008 \mathrm{de}$ & $0.618 \pm 0.036 \mathrm{c}$ & $0.234 \pm 0.006 \mathrm{bd}$ & $0.205 \pm 0.062 \mathrm{~b}$ & $1.025 \pm 0.006 \mathrm{~b}$ & $0.886 \pm 0.028 \mathrm{~b}$ \\
\hline
\end{tabular}

Data are mean \pm SD $(n=5)$. Different lowercase letters in the same column indicate significant difference at $\mathrm{p}<0.05$ levels between different treatments according to the LSD

\section{Free proline content}

As one of the most important osmotic substances in plants, the accumulation of free proline plays an important role for osmotic regulation of cells, stabilization of cell structure and reduction of oxidation (Dawood et al., 2014). Under normal circumstances, the content of free proline keeps at comparatively low level. However, under the adverse conditions such as salinization, drought, heavy metal pollution, etc., free proline will accumulate in cytoplasm to resist stress and carry out osmotic adjustment (Ali et al., 2015). Under $\mathrm{Pb}$, Cd single and combined stress, the contents of free proline were all higher than CK and increased with concentration during $45 \mathrm{~d}$ and $90 \mathrm{~d}$ treatment processes. Under the same treatment, when the concentration of 
$\mathrm{Pb}>800 \mathrm{mg} / \mathrm{kg}$ and $\mathrm{Cd}>5 \mathrm{mg} / \mathrm{kg}$, the amount of free proline decreased with time, yet under $\mathrm{Pb}+\mathrm{Cd}$ stress, free proline content increased with time (see Table 3).

Table 3. Effect of $\mathrm{Pb}, \mathrm{Cd}$ stress on the content of free proline $\mathrm{mg} / \mathrm{g}$

\begin{tabular}{|c|c|c|c|c|c|c|}
\hline \multirow{3}{*}{ Treatment } & \multicolumn{6}{|c|}{ Element } \\
\hline & \multicolumn{2}{|c|}{ Cd } & \multicolumn{2}{|c|}{$\mathbf{P b}$} & \multicolumn{2}{|c|}{$\mathbf{C d}+\mathbf{P b}$} \\
\hline & 45d & 90d & $45 d$ & 90d & $45 d$ & 90d \\
\hline $\mathrm{CK}$ & $0.112 \pm 0.004 \mathrm{a}$ & $0.131 \pm 0.010 \mathrm{a}$ & $0.112 \pm 0.004 \mathrm{a}$ & $0.131 \pm 0.010 \mathrm{a}$ & $0.112 \pm 0.004 \mathrm{a}$ & $0.131 \pm 0.010 \mathrm{a}$ \\
\hline 1 & $0.141 \pm 0.014 \mathrm{a}$ & $0.164 \pm 0.042 b$ & $0.145 \pm 0.021 \mathrm{ac}$ & $0.168 \pm 0.003 \mathrm{ac}$ & $0.168 \pm 0.005 \mathrm{a}$ & $0.174 \pm 0.035 \mathrm{a}$ \\
\hline 2 & $0.162 \pm 0.036 \mathrm{a}$ & $0.343 \pm 0.003 \mathrm{c}$ & $0.260 \pm 0.034 b c$ & $0.366 \pm 0.021 b c$ & $0.170 \pm 0.056 \mathrm{a}$ & $0.184 \pm 0.008 \mathrm{a}$ \\
\hline 3 & $0.390 \pm 0.054 b$ & $0.351 \pm 0.023 \mathrm{c}$ & $0.468 \pm 0.017 \mathrm{~d}$ & $0.281 \pm 0.065 b c$ & $0.894 \pm 0.097 \mathrm{~b}$ & $1.183 \pm 0.108 b$ \\
\hline 4 & $0.711 \pm 0.026 \mathrm{c}$ & $0.543 \pm 0.045 \mathrm{c}$ & $0.750 \pm 0.077 \mathrm{e}$ & $0.473 \pm 0.005 \mathrm{~d}$ & $1.208 \pm 0.078 \mathrm{~d}$ & $1.263 \pm 0.016 \mathrm{~b}$ \\
\hline
\end{tabular}

Data are mean \pm SD $(n=5)$. Different lowercase letters in the same column indicate significant difference at $\mathrm{p}<0.05$ levels between different treatments according to the LSD

\section{Soluble sugar content}

Soluble sugar, the main osmotica for plants, has a stabilization effect for cell membrane and protoplasmic colloid and a protective effect when the concentration of inorganic ions is high in cells. Under osmotic stress, plants can reduce osmosis by accumulating soluble sugar to adapt to changes of environment (Nawaz et al., 2015) According to data in Table 4, soluble sugar content showed a downtrend as treatment time prolonged under the same treatment of $\mathrm{Pb}, \mathrm{Cd}$ single and combined stress at $45 \mathrm{~d}$ and $90 \mathrm{~d}$. For concentration, when it increased, soluble sugar content of each group all showed a gradually rising tendency compared to $\mathrm{CK}$ and reached the highest at treatment 4. For $\mathrm{Pb}$ stress only, soluble content increased $43.94 \%$ and $46.09 \%$ respectively in contrast to $\mathrm{CK}$ at $45 \mathrm{~d}$ and $90 \mathrm{~d}$. For Cd stress, the percentages were $61.36 \%$ and $54.69 \%$, whereas $70.45 \%$ and $57.81 \%$ for $\mathrm{Pb}+\mathrm{Cd}$ combined stress.

Table 4. Effect of $\mathrm{Pb}, \mathrm{Cd}$ stress on soluble sugar $\mathrm{mg} / \mathrm{g}$

\begin{tabular}{|c|c|c|c|c|c|c|}
\hline \multirow{3}{*}{ Treatment } & \multicolumn{6}{|c|}{ Element } \\
\hline & \multicolumn{2}{|c|}{ Cd } & \multicolumn{2}{|c|}{$\mathbf{P b}$} & \multicolumn{2}{|c|}{$\mathbf{C d}+\mathbf{P b}$} \\
\hline & 45d & 90d & 45d & 90d & 45d & 90d \\
\hline CK & $0.132 \pm 0.014 \mathrm{a}$ & $0.128 \pm 0.012 \mathrm{a}$ & $0.132 \pm 0.014 \mathrm{a}$ & $0.128 \pm 0.012 \mathrm{a}$ & $0.132 \pm 0.014 \mathrm{a}$ & $0.128 \pm 0.012 \mathrm{a}$ \\
\hline 1 & $0.145 \pm 0.015 \mathrm{a}$ & $0.138 \pm 0.023 \mathrm{a}$ & $0.143 \pm 0.002 \mathrm{a}$ & $0.132 \pm 0.044 \mathrm{a}$ & $0.149 \pm 0.008 \mathrm{a}$ & $0.144 \pm 0.022 \mathrm{a}$ \\
\hline 2 & $0.160 \pm 0.007 \mathrm{a}$ & $0.153 \pm 0.034 \mathrm{a}$ & $0.159 \pm 0.042 \mathrm{a}$ & $0.155 \pm 0.130 \mathrm{a}$ & $0.170 \pm 0.015 \mathrm{ac}$ & $0.163 \pm 0.004 \mathrm{a}$ \\
\hline 3 & $0.174 \pm 0.021 \mathrm{ac}$ & $0.163 \pm 0.050 \mathrm{a}$ & $0.170 \pm 0.003 \mathrm{a}$ & $0.164 \pm 0.026 \mathrm{a}$ & $0.194 \pm 0.015 \mathrm{ad}$ & $0.183 \pm 0.050 \mathrm{a}$ \\
\hline 4 & $0.213 \pm 0.005 b c$ & $0.198 \pm 0.033 \mathrm{a}$ & $0.190 \pm 0.034 \mathrm{a}$ & $0.187 \pm 0.033 \mathrm{a}$ & $0.225 \pm 0.027 \mathrm{bcd}$ & $0.202 \pm 0.020 \mathrm{a}$ \\
\hline
\end{tabular}

Data are mean \pm SD $(n=5)$. Different lowercase letters in the same column indicate significant difference at $\mathrm{p}<0.05$ levels between different treatments according to the LSD

\section{Soluble protein content}

Soluble proteins are typical enzymes that specifically bind to the membrane system. Under certain stresses, the higher the content of soluble protein in plants, the stronger the physiological and biochemical reactions and metabolic activities of the plant, which can be used as an indicator of plant's relative resistance. In Table 5, Soluble protein 
content decreased with the increase of time when under the same treatment at $45 \mathrm{~d}$ and $90 \mathrm{~d}$ separately, The soluble protein content of each treatment was higher than control no matter single or combined stress and increased with concentration.

Table 5. Effect of $P b, C d$ stress on soluble protein $\mathrm{mg} / \mathrm{g}$

\begin{tabular}{|c|c|c|c|c|c|c|}
\hline \multirow{3}{*}{ Treatment } & \multicolumn{6}{|c|}{ Element } \\
\hline & \multicolumn{2}{|c|}{ Cd } & \multicolumn{2}{|c|}{$\mathbf{P b}$} & \multicolumn{2}{|c|}{$\mathbf{C d}+\mathbf{P b}$} \\
\hline & 45d & 90d & 45d & 90d & 45d & 90d \\
\hline $\mathrm{CK}$ & $0.302 \pm 0.027 \mathrm{a}$ & $0.181 \pm 0.003 \mathrm{a}$ & $0.302 \pm 0.027 \mathrm{a}$ & $0.181 \pm 0.003 \mathrm{a}$ & $0.302 \pm 0.027 \mathrm{a}$ & $0.181 \pm 0.003 \mathrm{a}$ \\
\hline 1 & $0.493 \pm 0.033 \mathrm{ac}$ & $0.282 \pm 0.210 \mathrm{ac}$ & $0.545 \pm 0.035 b$ & $0.438 \pm 0.019 b$ & $1.148 \pm 0.187 \mathrm{~b}$ & $1.124 \pm 0.196 \mathrm{~b}$ \\
\hline 2 & $0.660 \pm 0.046 \mathrm{bc}$ & $0.453 \pm 0.025 \mathrm{ad}$ & $0.759 \pm 0.036 b$ & $0.555 \pm 0.066 \mathrm{~b}$ & $1.270 \pm 0.109 \mathrm{~b}$ & $1.163 \pm 0.098 b$ \\
\hline 3 & $0.820 \pm 0.044 b$ & $0.633 \pm 0.075 \mathrm{bcd}$ & $0.870 \pm 0.058 \mathrm{~b}$ & $0.764 \pm 0.036 \mathrm{c}$ & $2.194 \pm 0.202 \mathrm{c}$ & $2.183 \pm 0.311 \mathrm{c}$ \\
\hline 4 & $1.102 \pm 0.142 \mathrm{~d}$ & $0.188 \pm 0.001 \mathrm{a}$ & $1.200 \pm 0.113 c$ & $0.188 \pm 0.101 \mathrm{a}$ & $3.218 \pm 0.237 \mathrm{~d}$ & $3.195 \pm 0.214 \mathrm{~d}$ \\
\hline
\end{tabular}

Data are mean \pm SD $(n=5)$. Different lowercase letters in the same column indicate significant difference at $\mathrm{p}<0.05$ levels between different treatments according to the LSD

\section{MDA content}

MDA is the main decomposition product of membrane lipid peroxidase and one of the main parameters reflecting the degree of damage to membrane system (Magwanga et al., 2018). In Table 6, the result showed that MDA contents of both single and combined stress were higher than $\mathrm{CK}$ at high concentrations. which pointed that high concentrations treatments had damage to plant. Under $\mathrm{Pb}, \mathrm{Cd}$ single stress, MDA contents of Japanese honeysuckle leaves were higher than CK by $2.62 \%$ to $124.8 \%$. While under combined stress, it was higher than CK by $14.24 \%$ to $104.31 \%$. At different treatment time, MDA content increased as treatment time increased, which meant that as time prolonged, the damage of membrane lipid peroxidation increased and the ability to clear active oxygen decreased. For single treatment, MDA content increased as treatment concentration increased, indicating that Japanese honeysuckle growth was inhibited to a certain extent. Whereas MDA content had no apparent increase with concentration increase under combined stress, indicating that Japanese honeysuckle was not sensitive to the aggravation of adverse stress under the combined stress.

\section{POD content}

POD, a common redox enzyme in plants, is a kind of enzyme with high activity. As a type of enzyme that is very sensitive to environmental factors (Ashraf et al., 2017). It can catalyze the oxidative decomposition of toxic substances. At the $45 \mathrm{~d}$ and $90 \mathrm{~d}$, POD activity of Japanese honeysuckle leaves increased as treatment concentration

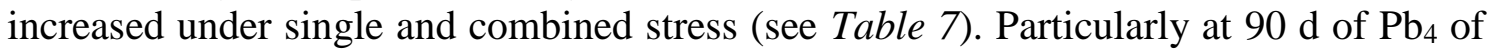
single stress, POD activity increased by up to $107.45 \%$, which manifested that under high concentration of $\mathrm{Pb}$ treatment, POD acted as protection for heavy metal damage. When under Cd stress, POD activity first increased with treatment concentration. As treatment time prolonged, its activity dropped when Cd concentration $\geqq 5.0 \mathrm{mg} / \mathrm{kg}$, but was still higher than $\mathrm{CK}$, indicating that when $\mathrm{Cd}$ concentration was beyond the tolerance of plant, POD activity was inhibited. POD activity under combined stress was similar to that under $\mathrm{Cd}$ stress. When the concentration of 
$\mathrm{Pb}+\mathrm{Cd}>1.0 \mathrm{mg} / \mathrm{kg}+600 \mathrm{mg} / \mathrm{kg}$, POD activity began to drop, however, it was still higher than $\mathrm{CK}$ and $\mathrm{Pb}, \mathrm{Cd}$ stress, indicating synergistic effect of $\mathrm{Pb}$ and $\mathrm{Cd}$. At low concentration, POD activity's increase shows raise in its capacity of scavenging oxygen free radicals and its decrease at high concentration indicates its limitation of defense mechanism.

Table 6. Effect of Pb, Cd stress on MDA content $\mu \mathrm{mol} / \mathrm{g}$

\begin{tabular}{c|c|c|c|c|c|c}
\hline \multirow{2}{*}{ Treatment } & \multicolumn{6}{|c}{ Element } \\
\cline { 2 - 7 } & \multicolumn{2}{|c|}{ Cd } & \multicolumn{2}{c}{ Pb } & \multicolumn{2}{c}{ Cd Pb } \\
\cline { 2 - 7 } & 45d & 90d & 45d & 90d & 45d & 90d \\
\hline CK & $0.344 \pm 0.020 \mathrm{a}$ & $0.371 \pm 0.071 \mathrm{a}$ & $0.344 \pm 0.020 \mathrm{a}$ & $0.371 \pm 0.071 \mathrm{a}$ & $0.344 \pm 0.020 \mathrm{a}$ & $0.371 \pm 0.071 \mathrm{a}$ \\
1 & $0.353 \pm 0.021 \mathrm{a}$ & $0.447 \pm 0.031 \mathrm{ac}$ & $0.353 \pm 0.052 \mathrm{a}$ & $0.437 \pm 0.044 \mathrm{ac}$ & $0.393 \pm 0.063 \mathrm{a}$ & $0.667 \pm 0.031 \mathrm{bd}$ \\
2 & $0.378 \pm 0.023 \mathrm{ac}$ & $0.576 \pm 0.035 \mathrm{bc}$ & $0.458 \pm 0.026 \mathrm{ac}$ & $0.478 \pm 0.047 \mathrm{ac}$ & $0.478 \pm 0.047 \mathrm{ac}$ & $0.676 \pm 0.038 \mathrm{be}$ \\
3 & $0.399 \pm 0.024 \mathrm{ac}$ & $0.664 \pm 0.037 \mathrm{be}$ & $0.566 \pm 0.031 \mathrm{bc}$ & $0.568 \pm 0.035 \mathrm{bc}$ & $0.499 \pm 0.045 \mathrm{ac}$ & $0.567 \pm 0.027 \mathrm{~b}$ \\
4 & $0.449 \pm 0.026 \mathrm{bc}$ & $0.753 \pm 0.039 \mathrm{de}$ & $0.770 \pm 0.042 \mathrm{~d}$ & $0.834 \pm 0.053 \mathrm{~d}$ & $0.639 \pm 0.049 \mathrm{bc}$ & $0.758 \pm 0.057 \mathrm{cde}$ \\
\hline
\end{tabular}

Data are mean \pm SD $(n=5)$. Different lowercase letters in the same column indicate significant difference at $\mathrm{p}<0.05$ levels between different treatments according to the LSD

Table 7. Effect of Pb, Cd stress on POD activity $U / g$

\begin{tabular}{c|c|c|c|c|c|c}
\hline \multirow{2}{*}{$\begin{array}{c}\text { Treat- } \\
\text { ment }\end{array}$} & \multicolumn{2}{|c|}{ Cd } & \multicolumn{2}{c}{ Pb } & \multicolumn{2}{c}{ Cd+Pb } \\
\cline { 2 - 7 } & $\mathbf{4 5 d}$ & $\mathbf{9 0 d}$ & $\mathbf{4 5 d}$ & $\mathbf{9 0 d}$ & $\mathbf{4 5 d}$ & $\mathbf{9 0 d}$ \\
\hline $\mathrm{CK}$ & $311.43 \pm 35.54 \mathrm{a}$ & $350.56 \pm 20.58 \mathrm{a}$ & $311.43 \pm 35.54 \mathrm{a}$ & $350.56 \pm 20.58 \mathrm{a}$ & $311.43 \pm 35.54 \mathrm{a}$ & $350.56 \pm 20.58 \mathrm{a}$ \\
1 & $419.88 \pm 37.70 \mathrm{ac}$ & $454.83 \pm 70.56 \mathrm{ac}$ & $324.56 \pm 29.56 \mathrm{ac}$ & $368.84 \pm 21.20 \mathrm{ac}$ & $431.56 \pm 17.72 \mathrm{ac}$ & $458.84 \pm 25.47 \mathrm{ac}$ \\
2 & $420.52 \pm 23.64 \mathrm{bc}$ & $438.88 \pm 12.68 \mathrm{ad}$ & $335.67 \pm 20.84 \mathrm{ad}$ & $378.42 \pm 28.27 \mathrm{ad}$ & $511.47 \pm 35.73 \mathrm{bc}$ & $522.42 \pm 33.44 \mathrm{ad}$ \\
3 & $483.49 \pm 13.82 \mathrm{bc}$ & $472.56 \pm 41.23 \mathrm{ae}$ & $426.97 \pm 32.85 \mathrm{bcd}$ & $482.63 \pm 60.65 \mathrm{bcd}$ & $567.66 \pm 22.87 \mathrm{~b}$ & $544.34 \pm 80.57 \mathrm{bcd}$ \\
4 & $600.76 \pm 32.13 \mathrm{~d}$ & $582.34 \pm 19.64 \mathrm{bcde}$ & $648.53 \pm 33.67 \mathrm{e}$ & $727.22 \pm 29.56 \mathrm{e}$ & $569.56 \pm 53.16 \mathrm{~b}$ & $545.72 \pm 26.51 \mathrm{bcd}$ \\
\hline
\end{tabular}

Data are mean \pm SD $(n=5)$. Different lowercase letters in the same column indicate significant difference at $\mathrm{p}<0.05$ levels between different treatments according to the LSD

\section{SOD content}

SOD is one of the most important protective enzymes for scavenging active free radicals in plants. It can effectively clear excessive oxygen free radicals in plants and reduce its peroxide degree on membrane lipids (Malar et al., 2014). According to the data in Table 8, compared between $45 \mathrm{~d}$ and $90 \mathrm{~d}$, the activity of enzyme decreased with the prolong of treatment time. The activity of SOD increased as the treatment concentration increased under single and combined stress, however, it was not so apparent compared to the control, indicating that the influence of $\mathrm{Pb}, \mathrm{Cd}$ stress was not so obvious on the activity of SOD.

\section{CAT content}

As an important redox enzyme in plants as well as a key enzyme for biological defense system, CAT can scavenge superfluous active oxygen, maintain the balance of active oxygen metabolism and protect the integrity of cell membrane (Khan et al., 2018; Anjum et al., 2015). Under single and combined treatment, with the increase of treatment time and concentration, the activity of CAT showed an increasing trend, 
indicating that Japanese honeysuckle leaves can adapt to long time adverse environment by increasing the activity of CAT. The activity of CAT increased more when the concentration of $\mathrm{Cd}>1.0 \mathrm{mg} / \mathrm{kg}, \mathrm{Pb}>600 \mathrm{mg} / \mathrm{kg}, \mathrm{Pb}+\mathrm{Cd}>600 \mathrm{mg} / \mathrm{kg}+1.0 \mathrm{mg} / \mathrm{kg}$ at $90 \mathrm{~d}$. The increase amplitudes were $50.31 \%, 45.6 \%$ and $70.14 \%$ respectively, among which the combined stress had the highest increase (see Table 9). The results showed that high concentrations of $\mathrm{Pb}$ and $\mathrm{Cd}$ stress could promote the increase of CAT activity in leaves of Japanese honeysuckle and the $\mathrm{Pb}$ and $\mathrm{Cd}$ combined stress had corresponding synergistic effect.

Table 8. Effect of Pb, Cd stress on SOD activity $U / g$

\begin{tabular}{|c|c|c|c|c|c|c|}
\hline \multirow{3}{*}{ Treatment } & \multicolumn{6}{|c|}{ Element } \\
\hline & \multicolumn{2}{|c|}{ Cd } & \multicolumn{2}{|c|}{$\mathbf{P b}$} & \multicolumn{2}{|c|}{$\mathbf{C d}+\mathbf{P b}$} \\
\hline & $45 d$ & 90d & 45d & 90d & 45d & 90d \\
\hline $\mathrm{CK}$ & $580.98 \pm 35.54 a$ & $540.77 \pm 28.93 a$ & $580.98 \pm 35.54 \mathrm{a}$ & $540.77 \pm 28.93 a$ & $580.98 \pm 35.54 a$ & $540.77 \pm 28.93 a$ \\
\hline 1 & $544.46 \pm 32.63 \mathrm{a}$ & $589.32 \pm 28.56 \mathrm{a}$ & $594.56 \pm 29.56 \mathrm{a}$ & $558.64 \pm 28.76 \mathrm{a}$ & $621.56 \pm 40.72 \mathrm{a}$ & $588.84 \pm 29.33 \mathrm{a}$ \\
\hline 2 & $591.52 \pm 15.23 \mathrm{a}$ & $548.77 \pm 22.58 \mathrm{a}$ & $605.47 \pm 37.66 \mathrm{a}$ & $568.42 \pm 28.27 \mathrm{a}$ & $641.47 \pm 39.90 \mathrm{a}$ & $612.42 \pm 33.44 a$ \\
\hline 3 & $625.46 \pm 32.65 \mathrm{a}$ & $582.73 \pm 0.023 \mathrm{a}$ & $613.48 \pm 32.65 \mathrm{a}$ & $605.46 \pm 32.65 \mathrm{ac}$ & $666.73 \pm 32.87 \mathrm{a}$ & $633.43 \pm 50.52 \mathrm{a}$ \\
\hline 4 & $621.88 \pm 35.31 \mathrm{a}$ & $571.34 \pm 29.56 \mathrm{a}$ & $739.56 \pm 33.67 b$ & $697.77 \pm 29.56 b c$ & $689.56 \pm 43.16 \mathrm{a}$ & $655.23 \pm 43.11 \mathrm{a}$ \\
\hline
\end{tabular}

Data are mean \pm SD $(n=5)$. Different lowercase letters in the same column indicate significant difference at $\mathrm{p}<0.05$ levels between different treatments according to the LSD

Table 9. Effect of $P b, C d$ stress on CAT activity $U / g$

\begin{tabular}{c|c|c|c|c|c|c}
\hline \multirow{2}{*}{ Treatment } & \multicolumn{6}{|c}{ Element } \\
\cline { 2 - 7 } & \multicolumn{2}{|c|}{ Cd } & \multicolumn{2}{c}{ Pb } & \multicolumn{2}{c}{ Cd+Pb } \\
\cline { 2 - 7 } & $\mathbf{4 5 d}$ & $\mathbf{9 0 d}$ & $\mathbf{4 5 d}$ & $\mathbf{9 0 d}$ & $\mathbf{4 5 d}$ & $\mathbf{9 0 d}$ \\
\hline CK & $14.34 \pm 0.86 \mathrm{a}$ & $14.67 \pm 1.87 \mathrm{a}$ & $14.34 \pm 0.86 \mathrm{ac}$ & $14.67 \pm 1.87 \mathrm{a}$ & $14.34 \pm 0.86 \mathrm{a}$ & $14.67 \pm 1.87 \mathrm{a}$ \\
1 & $14.94 \pm 2.18 \mathrm{ac}$ & $15.72 \pm 1.05 \mathrm{ac}$ & $12.32 \pm 0.43 \mathrm{ac}$ & $14.63 \pm 1.21 \mathrm{a}$ & $16.45 \pm 0.27 \mathrm{a}$ & $17.76 \pm 0.29 \mathrm{ac}$ \\
2 & $17.60 \pm 1.12 \mathrm{ad}$ & $17.78 \pm 1.18 \mathrm{ad}$ & $15.33 \pm 0.23 \mathrm{ac}$ & $16.78 \pm 0.14 \mathrm{ac}$ & $18.51 \pm 0.31 \mathrm{ac}$ & $19.87 \pm 0.16 \mathrm{bc}$ \\
3 & $20.21 \pm 0.39 \mathrm{bc}$ & $21.13 \pm 1.42 \mathrm{bc}$ & $18.81 \pm 1.29 \mathrm{~b}$ & $19.88 \pm 0.51 \mathrm{bc}$ & $20.81 \pm 1.51 \mathrm{bc}$ & $22.92 \pm 0.63 \mathrm{be}$ \\
4 & $20.92 \pm 1.79 \mathrm{bd}$ & $22.05 \pm 0.64 \mathrm{bd}$ & $19.31 \pm 0.25 \mathrm{~b}$ & $21.36 \pm 0.12 \mathrm{~b}$ & $21.36 \pm 1.72 \mathrm{~b}$ & $24.96 \pm 0.15 \mathrm{de}$ \\
\hline
\end{tabular}

Data are mean \pm SD $(n=5)$. Different lowercase letters in the same column indicate significant difference at $\mathrm{p}<0.05$ levels between different treatments according to the LSD

\section{Discussion}

Under heavy metal stress, three kinds of osmosis substances, free proline, soluble sugar, soluble protein, accumulated quickly in leaves to reduce osmotic potential in cells, increase osmotic adjustment ability, promote moisture absorption and ensure the norm growth of plants. However, after $45 \mathrm{~d}$ of single treatment, the contents of soluble sugar, soluble protein and free proline increased. Both soluble sugar and soluble protein contents decreased after $90 \mathrm{~d}$ of single and combined stress. These results are correlated with work of Janmohammadi et al. (2013). This might be caused by physiological mechanism damage of plants after long time single or combined stress, which might inhibit the accumulation of soluble sugar and soluble protein, accelerate their decomposition and reduce their contents. One reason, which might explain the increase of soluble sugar, is that plants can regulate osmotic potential to reduce damage caused 
by outside environment through increasing soluble sugar content. Since a large number of increased organic small solutes like soluble protein can reduce water potential in cells so as to achieve the purpose of water absorption from the surrounding cells. The other reason might be that under heavy metal stress, the absorption of some essential ions weakened, leading to accelerated decomposition of substances such as starch, protein and nucleic acids, thus plant growth was inhibited. The content of soluble sugar in leaves of Japanese honeysuckle treated with heavy metal stress decreased 90 days compared with 45 days, which may be due to the consumption of plant respiration as time went by. Soluble sugar content in Japanese honeysuckle leaves under $\mathrm{Pb}, \mathrm{Cd}$ single stress or $\mathrm{Pb}+\mathrm{Cd}$ combined stress was comparatively high, which might improve the capacity of stress tolerance of plants. Free proline can still maintain a higher concentration. These findings are correlated with work of Jayasri et al. (2017). Their study of $\mathrm{Pb}$ stress on Lemna minor demonstrated that the decomposition of soluble protein accelerated under adverse circumstances and separated into various amino acid including free proline, etc., resulting in the rise of proline content. Due to the low osmotic potential of the external environment under heavy metal stress, plants will lose water. In order to avoid infiltration injury, plant cells will take the initiative to absorb and accumulate inorganic salts and soluble substances such as free proline to reduce intracellular osmotic potential and avoid water loss damage. In our study, the higher content of free proline under high concentration of heavy metal stress may be related to this, however, the specific reasons still need further analysis. Stress changes substances metabolism of plants and generates osmotic adjustment substances to accumulate in plants, such as macro molecular substances like starch, protein, which further break down into small molecules such as soluble sugar, soluble protein and free proline. These substances have strong hydrophilic property, stabilizing colloidal property, protecting plant cells from damage or reducing damage in tissue metabolism. The capacity of osmotic adjustment of these substances can directly reflect the strength of stress resistance of plants.

When the reactive oxygen species produced in plant cells under heavy metal stress are beyond scavenging activity of protective enzyme system, free radicals will accumulate in leaf cells, thereby inducing peroxidase damage of plant cells. As one of the antioxidant enzymes, POD plays an important role for plants to resist adversity stress. In our study, $\mathrm{Pb}, \mathrm{Cd}$ stress have effects for SOD, POD and CAT activities. However, the activity of POD increased more than that of SOD and CAT. $45 \mathrm{~d}$ after treatment, under low concentration and high concentration of $\mathrm{Pb}, \mathrm{Cd}$ single and combined stress, the activities of SOD, POD and CAT all increased to protect Japanese honeysuckle from injury. When the concentration of stress was higher as time prolonged, POD activity further increased whereas SOD and CAT activities began to drop, indicating that POD played a major protective role in stress as the treatment time prolonged. When $\mathrm{Cd}$ concentration is in the range of $0.05-0.5 \mathrm{~mol} / \mathrm{L}$, the activity of POD and SOD increased with the increase of Cd concentration, but the content of MDA and the permeability of cell membrane also showed an upward trend (Santos et al., 2015). Although Cd increased the activity of POD and SOD to a certain extent, it did not prevent the occurrence of membrane hyperperoxide. Our study indicated that although $\mathrm{Pb}, \mathrm{Cd}$ stress have influence on SOD, POD and CAT activities, POD activity increased more than that of SOD and CAT. At $45 \mathrm{~d}$ of treatment, under low and high concentrations of $\mathrm{Pb}, \mathrm{Cd}$ stresses or $\mathrm{Pb}+\mathrm{Cd}$ combined stress, the activities of SOD, POD, CAT all increased to protect Japanese honeysuckle from injury. At $90 \mathrm{~d}$ of 
treatment, when $\mathrm{Pb}, \mathrm{Cd}$ stress or combined stress were of high concentrations, POD activity further increased while SOD and CAT activities began to drop, manifesting that POD act as the main protector under stress with the increase of time. The study showed that Japanese honeysuckle reduce metabolism imbalance damage through increasing osmotic adjustment substances of leaves and inducing the scavenging system of reactive oxygen in a certain range of heavy metal stress.

\section{Conclusions}

1. In our study, heavy metal stress hindered CHL synthesis to different extents at $45 \mathrm{~d}$ and $90 \mathrm{~d}$. At $90 \mathrm{~d}$, the content of CHL was lower than $45 \mathrm{~d}$, which illustrated that heavy metal stress inhibited CHL synthesis as treatment time prolonged.

2. In our study, all the evidence pointed to the fact that under heavy metal stress, three kinds of osmosis substances, free proline, soluble sugar, soluble protein, accumulated quickly in leaves of Japanese honeysuckle to reduce osmotic potential in cells, increase osmotic adjustment ability, promote moisture absorption and ensure the norm growth of plants. The contents of soluble sugar, soluble protein and free proline increased after $45 \mathrm{~d}$ of single treatment. Both soluble sugar and soluble protein contents decreased after $90 \mathrm{~d}$ of single and combined stress. This might be caused by physiological mechanism damage of plants after long time single or combined stress, which might inhibit the accumulation of soluble sugar and soluble protein, accelerate their decomposition and reduce their contents. Free proline can still maintain a higher concentration.

3. In our study, $\mathrm{Pb}, \mathrm{Cd}$ stresses have effects for $\mathrm{SOD}, \mathrm{POD}$ and CAT activities. However, the activity of POD increased more than that of SOD and CAT. $45 \mathrm{~d}$ after treatment, under low concentration and high concentration of $\mathrm{Pb}, \mathrm{Cd}$ single and combined stress, the activities of SOD, POD and CAT all increased to protect Japanese honeysuckle from injury. When the concentration of stress was higher as time prolonged, POD activity further increased whereas SOD and CAT activities began to drop, indicating that POD played a major protective role in stress as the treatment time prolonged. With the increase of $\mathrm{Cd}$ concentration, the content of MDA and the permeability of cell membrane also showed an upward trend. Although $\mathrm{Cd}$ increased the activity of POD and SOD to a certain extent, it did not prevent the occurrence of membrane hyperperoxide.

4. The study showed that Japanese honeysuckle can reduce metabolism imbalance damage through increasing osmotic adjustment substances of leaves and inducing the scavenging system of reactive oxygen in a certain range of heavy metal stress.

Acknowledgements. This work was supported by the Science and Technology Key Projects of Henan Province (152102310018); Key Scientific Research Project of colleges and university in Henan Province (16A180049).

\section{REFERENCES}

[1] Aebi, H. (1984): Catalase in vitro methods. - Enzymol 105: 121-126.

[2] Ali, N., Hadi, F. (2015): Phytoremediation of cadmium improved with the high production of endogenous phenolics and free proline contents in Parthenium 
hysterophorus plant treated exogenously with plant growth regulator and chelating agent. - Environmental Science Pollution Research 22(17): 13305-13318.

[3] Anjum, S. A., Tanveer, M., Hussain, S. et al. (2015): Cadmium toxicity in maize (Zea mays L.): consequences on antioxidative systems, reactive oxygen species and cadmium accumulation. - Environmental Science and Pollution Research 22(21): 17022-17030.

[4] Anjum, S. A., Tanveer, M., Hussain, S. et al. (2016): Morpho-physiological growth and yield responses of two contrasting maize cultivars to cadmium exposure. - Clean-Soil Air Water 44(1): 29-36.

[5] Arnon, D. I. (1949): Copper enzymes in isolated chloroplasts. Polyphenodxidase in Beta vulgaris. - Plant Physiol 24(1): 1.

[6] Ashraf, U., Hussain, S., Anjum, S. A. et al. (2017): Alterations in growth, oxidative damage, and metal uptake of five aromatic rice cultivars under lead toxicity. - Plant Physiol Biochem 115: 461-471.

[7] Bestwick, G. S., Brown, I. R., Mansfield, J. W. (1998): Localized changes in peroxidase activity accompany hydrogen peroxide generation during the development of anonhost hypersensitive reaction in lettuce. - Plant Physiology 118: 1067-1078.

[8] Chen, D. D., Xie, X. F., Ao, H., Liu, J. L., Peng, C. (2017): Raman spectroscopy in quality control of Chinese herbal medicine. - Journal of the Chinese Medical Association 80: 288-296.

[9] Dawood, M. G., Taie, H. A. A., Nassar, R. M. A. et al. (2014): The changes induced in the physiological, biochemical and anatomical characteristics of Vicia faba by the exogenous application of proline under seawater stress. - South African Journal of Botany 93: 54-63.

[10] Elavarthi, S., Martin, B. (2010): Spectrophotometric assays for antioxidant enzymes in plants, in plant stress tolerance. - Methods and Molecular Biology 639: 273-280.

[11] Fairbairn, N. J. (1953): A modified anthrone reagent. - Chem and Ind. 4: 86.

[12] Hossain, S. (2019): Seismic geomorphology as a tool for reservoir characterization: a case study from Moragot Field of Pattani Basin, Gulf of Thailand. - Malaysian Journal of Geosciences 3(1): 45-50.

[13] Hu, Y., Nan, Z., Jin, C., Wang, N., Luo, H. (2014): Phytoextraction potential of poplar (Populus alba L. var. pyramidalis Bunge) from calcareous agricultural soils contaminated by cadmium. - Int J Phytorem 16(5): 482-495.

[14] Jambunathan, N. (2010): Determination and detection of reactive oxygen species (ROS), lipid peroxidation, and electrolyte leakage in plants. - Methods in Molecular Biology 639: 292-298.

[15] Janmohammadi, M., Bihamta, M. R., Ghasemzadeh, F. (2013): Influence of rhizobacteria inoculation and lead stress on the physiological and biochemical attributes of wheat genotypes. - Cercet. Agron. in Mold. XLVI(1). DOI: https://doi.org/10.2478/v10298012-0074-x.

[16] Jayasri, M. A., Suthindhiran, K. (2017): Effect of zinc and lead on the physiological and biochemical properties of aquatic plant Lemna minor: its potential role in phytoremediation. - Appl. Water Sci. 7(3):1247-1253.

[17] Khan, M. M., Islam, E., Irem, S. et al. (2018a): Pb-induced phytotoxicity in para grass (Brachiaria mutica) and Castorbean (Ricinus communis L.): Antioxidant and ultrastructural studies. - Chemosphere 200: 257-265.

[18] Khan, J., Siddiq, M., Akram, B., Ashraf, M. A. (2018a): In-situ synthesis of CuO nanoparticles in P(NIPAM-co-AAA) microgel, structural characterization, catalytic and biological applications. - Arabian Journal of Chemistry 11(6) 897-909.

[19] Li, C. L., Yang, M. Y., Zhu, L. J., Zhu, Y. Q. (2017): Honeysuckle flowers extract loaded bombyx morisilk fibroin films for inducing apoptosis of Hela cells. - Microscopy Research and Technique 80: 1297-1303.

[20] Liu, Z., Yang, Y., Bai, Y., Huang, Y., Nan, Z., Zhao, C., Ma, J., Wang, H. (2016): The effect of municipal sludge compost on the mobility and bioavailability of $\mathrm{Cd}$ in a 
sierozem-wheat system in an arid region northwest of China. - Environmental Science and Pollution Research 23(20): 20232-20242.

[21] Liu, Z. L., Chen, W., He XY. (2015): Influence of $\mathrm{Cd}^{2+}$ on growth and chlorophyll fluorescence in a hyperaccumulator: Lonicera japonica Thunb. - Plant Growth Regul 34(3): 672-676.

[22] Magwanga, R., Lu, P., Kirungu, J. et al. (2018): Whole genome analysis of cyclin dependent kinase (CDK) gene family in cotton and functional evaluation of the role of CDKF4 gene in drought and salt stress tolerance in plants. - International Journal of Molecular Sciences 19(9): 2625.

[23] Malar, S., Shivendra Vikram, S., Jc Favas, P., Perumal, V. (2014): Lead heavy metal toxicity induced changes on growth and antioxidative enzymes level in water hyacinths [Eichhornia crassipes (Mart.)]. - Botanical Studies 55(1): 54.

[24] Monteiro Junior, J. J., Silva, E. A., De Amorim Reis, A. L., Souza Santos, J. P. M. (2019): Dynamical spatial modeling to simulate the forest scenario in Brazilian dry forest landscapes. - Geology, Ecology, and Landscapes 3(1): 46-52: DOI: 10.1080/24749508.2018.1481658.

[25] Mostofa, M. G., Rahman, A., Ansary, M. D., Mesbah, U. et al. (2015): Hydrogen sulfide modulates cadmium-induced physiological and biochemical responses to alleviate cadmium toxicity in rice. - Scientific Reports 5: 14078.

[26] Muhammad, S., Hafiz, N. A., Zahir, A. Z., Muhammad, S. (2018): Impact of lead tolerant plant growth promoting rhizobacteria on growth, physiology, antioxidant activities, yield and lead content in sunflower in lead contaminated soil. - Chemosphere 195: 606-614.

[27] Nawaz, F., Ahmad, R., Ashraf, M. Y. et al. (2015): Effect of selenium foliar spray on physiological and biochemical processes and chemical constituents of wheat under drought stress. - Ecotoxicology and Environmental Safety 113: 191-200.

[28] Ogunkunle, T. J., Oyelami, O. A., Adepoju, A. O. (2019): Study of the phytodiversity along Antorun Reservoir, near Ogbomoso, Nigeria. - Environment \& Ecosystem Science 3(1): 1-12.

[29] Okpoli, C. C. (2019): Delineation of high-resolution aeromagnetic survey of Lower Benue Trough for lineaments and mineralization: case study of Abakikili Sheet 303. Malaysian Journal of Geosciences 3(1): 51-60.

[30] Oyedotun, T. D. T. (2019): Land use change and classification in Chaohu Lake catchment from multi-temporal remotely sensed images. - Geology, Ecology, and Landscapes 3(1): 37-45. DOI: 10.1080/24749508.2018.1481657.

[31] Ran, J., Wang, D., Wang, C., Zhang, G., Zhang, H. (2016): Heavy metal contents, distribution, and prediction in a regional soil-wheat system. - Sci Total Environ 544: 422431.

[32] Riccardi, M., Mele, G., Pulvento, C. et al., (2014): Non-destructive evaluation of chlorophyll content in quinoa and amaranth leaves by simple and multiple regression analysis of RGB image components. - Photosynth Res 120(3): 263-272.

[33] Samsudin, M. S., Azid, A. (2018): Assessment of marine water quality index in mangrove estuarine: case study in Setiu River estuary. - Journal Clean WAS 2(2): 16-18.

[34] Santos, D., Duarte, B., Cacador, I. (2015): Biochemical and photochemical feedbacks of acute Cd toxicity in Juncus acutus seedlings: the role of non-functional Cd-chlorophylls. - Estuarine Coastal and Shelf Science.167: 228-239.

[35] Sarker, M. K. U., Majumder, A. K., Haque, M. Z., Hossain, M. S., Al Nayeem, A. (2019): Assessment of inland water quality parameters of Dhaka City, Bangladesh. Environment \& Ecosystem Science 3(1): 13-16.

[36] Schmidt, E. C., Felix, M. R. D. L., Polo, L. K. et al. (2015): Influence of cadmium and salinity in the red alga Pterocladiella capillacea: cell morphology, photosynthetic performance and antioxidant systems. - Brazilian Journal of Botany 38(4): 737-749.

[37] Sedmak, J. J., Grossberg, S. E. (1977): A rapid, sensitive, and versatile assay for protein using Coomassie brilliant blue G-250. - Anal. Biochem 79: 544-552. 
[38] Silva, A. J., Nascimento, C. W. A., Gouveia-Neto, A. S. (2017): Assessment of cadmium phytotoxicity alleviation by silicon using chlorophyll a fluorescence. - Photosynthetica 55(4): 648-654.

[39] Sufiyan, I., Magaji, J. I. (2018): Modeling flood hazard using swat and 3d analysis in Terengganu watershed. - Journal Clean Was 2(2): 19-24.

[40] Walter, T., John, L. (1955): A phptometric methods for the determination of proline. - J. Biol. Chem. 215: 655-660.

[41] Wang, D. Y., Zhao, X. M., Liu, Y. L. (2017): Hypoglycemic and hypolipidemic effects of a polysaccharide from flower buds of Lonicera japonica Thunb in streptozotocin-induced diabetic rats. - International Journal of Biological Macromolecules 102: 396-404.

[42] Wang, Y., Wang, S., Nan, Z., Ma, J., Zang, F., Chen, Y., Li, Y., Zhang, Q. (2015): Effects of $\mathrm{Ni}$ stress on the uptake and translocation of $\mathrm{Ni}$ and other mineral nutrition elements in mature wheat grown in sierozems from northwest of China. - Environ Sci Pollut Res 22(24): 19756-19763. 